\title{
Relationship of Nurse Motivation with The Implementation of Physical Examination of Patients
}

\author{
Muhammad Irwan' ${ }^{*}$, Aco Mursid ${ }^{2}$, Risnah ${ }^{3}$, Rosmah $^{4}$ \\ 1,2Jurusan Keperawatan Fakultas Ilmu Kesehatan, Universitas Sulawesi Barat, Indonesia \\ 3Jurusan Keperawatan Fakultas Kedokteran dan IImu Kesehatan UIN Alauddin Makassar, \\ Indonesia \\ ${ }^{4}$ Puskesmas Arungkeke, Kabupaten Jeneponto,Indonesia
}

Corresponding Autor : muhammad.irwan@unsulbar.ac.id

\begin{abstract}
Physical examination is one of the efforts to handle health to clients. Physical examination is carried out on the patient's body by means of inspection, palpation, percussion and auscultation to find out any changes in physiological function in the body. If the physical examination is not done by the nurse in doing nursing care, then the nursing diagnosis he sets will be wrong, and will actually cause new problems in patients. Of course, there are things that are the cause why a nurse does not do a physical examination, so research needs to be done to find the reason. The design used in this study is cross sectional studies. The results of the study were obtained with quisener and observation sheets on 58 respondents, namely 26 nurses in cempaka inpatient rooms and 32 nurses in dahlia inpatient rooms, knowing the relationship of motivation.
\end{abstract}

Keywords: Motivation, Physical Rating, Nurse

\section{INTRODUCTION}

The hospital is an organization that through medical personnel and professional paramedics organized as well as medical advice that permanently organizes medical services, continuous nursing care, diagnosis of treatment of diseases suffered by patients. Hospitals involve all health professional organizations to provide health services. Quality health care is a service supported by adequate human resources such as doctors, nurses, and other health professions. Nurses are one of the human resources that provide services and coaching to maintain and improve health and help people in the unique way possible to overcome the problems of daily life, injury, disability or death, the provision of nursing services is provided due to physical and mental weaknesses, limited knowledge and lack of progress towards the ability to carry out daily.

Nurses as nursing care providers are the most numerous health professions and serve clients in hospitals for 24 hours. Nursing care includes assessment, treatment, action plan, implementation and evaluation. The implementation of nursing care greatly 
affects the quality of health services in hospitals. The most basic thing in providing nursing care is the collection of information or data related to health problems experienced by clients to maintain the enforcement of nursing diagnoses. This process is carried out at the time of assessment using interview methods, observations and physical examinations.

Physical examination is one of the efforts to handle health to clients. Physical examination is carried out on the client's body by means of inspection, palpation, percussion and auscultation to determine any changes in physiological function in the body. Physical examination is the main basis of the nurse in determining the diagnosis and plan of action, the nurse will not be able to diagnose the right without conducting an assessment. In conducting a study that is long needed ability and willpower. Willpower is an aspect of motivation (Huber, 2010). Motivation means the extent to which a person moves to expend efforts in achieving a goal (Huber, 2010). The results of research by Mudayana (2010) show that motivation affects employee performance. Similar results obtained by Supriadi (2017) that motivation affects the performance of nurses in performing health services at Yogyakarta Islamic Hospital and Zahara research (2011) shows there is a relationship of work motivation with the performance of the managing nurse at RSPAD Gatot Seobroto. This shows that motivation greatly affects a parawat performance in applying nursing care.

Motivation is motivated by a need (Zulfan Saam, 2014). According to Abraham Maslow (Huber, 2010), humans behave or do things because of needs that must be met. Human needs are arranged in stages. There are five basic human needs according to Maslow: Physiological needs, safety needs, compassion needs, self-esteem needs, and self-actualization needs. According to Mc Clelland (Huber, 2010), the need to achieve is human mental power which is the drive to do something to achieve better results. Achievement motivation is a behavioral trait that leads to achievement, success, or better performance than others and trying to complete the activity uniquely. Motivation to achieve is an effort or struggle to achieve a superior standard. The nursing process is a systematic provision of nursing care, with the aim of identifying the health status of clients (Barbara Kozier, Glenora ERB, Audrey Berman, 2011).

The nursing process is an efficient method and is a framework needed in the application of nursing care. The nursing process is divided into five stages, namely assessment, determination of nursing diagnosis, action plan, implementation of nursing 
actions and evaluation (Setiadi, 2012).

Physical examination is part of the assessment process. Physical examination is an examination that is done to get supporting data in an anatomically systematic way from head to toe (Priharjo, 2007). As general physical examination can be done with the technique of inspection, which is a physical examination that is done by means of observation by using the nurse's vision to detect physical signs. Palpation is done by using touch or rebates to terminate tissues or organs. Percussion is done by tapping to determine the boundaries of organs and parts of the body by feeling the vibrations caused by the condemnation and Auscultation is a physical examination that is done using a stethoscope to clarify hearing, such as hearing heart sounds, intestinal noise, and others.

\section{MATERIALS AND METHODS}

Research design is a method used by researchers that determines the course of a study. The design used in this study is Cros sectional Study which measures variables in one unit of time (Dharma, 2017). The study was conducted by Cempak and Dahlia Hospital General Hospital Majene Region on September 20 - October 23, 2018. The sample in the study was a nurse. The study used questionnaires and observation sheets.

\section{RESULTS}

The results of the study were obtained as many as $\mathrm{n}=58$ respondents consisting of 26 from the Cempaka Room and 32 in the Dahlia Room. The majority of respondents were $72.4 \%(n=42)$ and had $46.6 \%(n=27)$ and DIII education status of $51.7 \%(n=30)$.

Tabel 1. Characteristic respondent $(n=58)$

\begin{tabular}{|c|c|c|}
\hline Characteristic & Frequency & Percentage \\
\hline \multicolumn{3}{|l|}{ Gender } \\
\hline Male & 16 & 27.6 \\
\hline Female & 42 & 72.4 \\
\hline \multicolumn{3}{|l|}{ Employment status } \\
\hline PNS & 9 & 15.5 \\
\hline Honorer & 27 & 46.6 \\
\hline Volunteer & 21 & 36.2 \\
\hline \multicolumn{3}{|l|}{ Level Of Education } \\
\hline $\mathrm{S} 2$ & - & - \\
\hline Ners & 7 & 12.1 \\
\hline $\mathrm{S} 1$ & 18 & 31 \\
\hline DIII & 30 & 51.7 \\
\hline SPK & 1 & 1.7 \\
\hline
\end{tabular}




\begin{tabular}{ccc} 
Cempaka & 26 & 44.8 \\
Dahlia & 32 & 55.2 \\
\hline Total & $\mathbf{5 8}$ & $\mathbf{1 0 0}$
\end{tabular}

Based on the results of observations made in the cempaka and dahlia inpatient rooms on September 20 - October 23, 2018 that from the safety of respondents in two rooms, 15 nurses (29.4\%) had high motivation to carry out physical examinations. While those who did not do as many as 38 nurses (70.6\%) despite having high motivation. For those who have moderate motivation who perform a physical examination is 1 person is not doing as many as 6 people.

Table. 2. Physical examination based on level of motivation

\begin{tabular}{ccccccc}
\hline Motivation & \multicolumn{4}{c}{ Phisical Assesment } & \multicolumn{2}{c}{ Total } \\
\cline { 2 - 5 } & \multicolumn{3}{c}{ Implemented } & \multicolumn{2}{c}{ Not Implemented } & \\
\hline High & 15 & $29.4 \%$ & 38 & $70.6 \%$ & 51 & $100 \%$ \\
Low & 1 & $14.3 \%$ & 6 & $85.7 \%$ & 7 & $100 \%$ \\
\hline Total & 16 & 16 & 44 & 76 & 58 & 210 \\
\hline
\end{tabular}

\section{DISCUSSION}

Motivation is something that can stimulate a person to do something of a job. From the results of the study showed still lack of motivation for nurses who did a complete physical examination it was seen that of the 58 respondents who had high motivation was 51 people but who carried out a complete physical examination was 15 people. This illustrates that the motivation is influenced by the level of knowledge from the nurse as well as the reward that will be given to the pearawat in carrying out a physical examination on the patient. This is supported by research conducted by wahyudi (2010) that most have excellent or high performance motivation with the reward and management of top managers.

It is also supported by (graphfin, 2004) that a manager can help these needs by providing various symbols of extrinsic achievement, such as rank, comfortable office and seripa. At the level of intrigue managers can provide challenging tasks and opportunities for employees to feel an achievement. Award needs cover internal awards such as awards, autonomy and achievement and external award factors such as status, recognition and attention (robbin, 2008). with a reward or reward to every nurse who has high motivation to carry out a physical examination. In research conducted by (indri ramadini) and (erni jasmita) The relationship of motivation with the performance of the managing nurse in the hospital hospital dr. Rasidin Padamg showed that there is a 
relationship between the performance of nurses and motivation that is influenced by the reward given. In the hospital majene is not adequate reward given to nurses.

Researchers argue that the implementation of physical examinations in patients can be carried out perfectly and completely if nurse nurses who have high motination are given rewards or awards to produce expected performance results. With the maximum reward given, there is no maximum implementation of physical examination. Physical examination is a physical assessment in obtaining supporting data in accordance with patient complaints to determine nursing diagnoses in the nursing process.

A complete physical examination includes a physical examination from the tip of the hair to the toe, but in general the nurse in the room only performs a physical examination only partly not carried out in full. This is because of motivation or the level of education and knowledge of nurses who are lacking. From research it can be concluded that motivation can improve the implementation of physical examination with the condition that the awarding of rewards or awards must also be adjusted.

\section{CONCLUSIONS}

There is a relationship between motivation and physical examination carried out by nurses. The implementation of a complete physical examination will be carried out well if the nurse is given a reward or award as motivation.

\section{REFERENCES}

Barbara Kozier, Glenora ERB, Audrey Berman, S. J. S. (2011). Fundamental Keperawatan Konsep, Proses dan Prakteik. (L. H. Dwi Widiarti, Eka Anisa Mardella, Nike Bhudi Subekti, Ed.) (7th ed.). Jakarta: EGC.

Dharma, K. K. (2017). Metode Penelitian Keperawatan. Jakarta: TIM.

Huber, D. L. (2010). Leadership And Nursing Care Management (4th ed.). Missouri: Saunders Elsevier.

Mudayana A A, (2010). Pengaruh motivasi dan beban kerja terhadap kinerja karyawan di Rumah sakit Nur Hidayatul Bantul.

Priharjo, R. (2007). Pengkajian fisik keperawatan. (P. E. Karyuni, Ed.). Jakarta: EGC.

Setiadi, (2012). Konsep dan penulisan dokumentasi asuhan keperawatan, Yogyakarta : Graha Ilmu.

Supriadi, (2017). Faktor-faktor yang berhubungan dengan kinerja perawat di Rumah Sakit Islam PDHI Yogyakarta. Healt Sciences and pharmacy Journal.

Zahara Y, Ratna Sitorus, Luknis Sabri, (2011). Faktor-faktor motivasi kerja : supervisi, penghasilan, dan hubungan interpersonal memengaruhi kinerja perawat pelaksana.

Zulfan Saam, S. W. (2014). Psikologi Keperawatan. Jakarta: Rajawali Pers. 